\title{
Miks kuulata muusikat ja vaikust?
}

\author{
Airi Liimets \\ Tallinna Ülikooli kasvatusfilosoofia ja kasvatussotsioloogia professor \\ airi_liimets@yahoo.de \\ Marit Koit \\ Tallinna Ülikooli haridusteaduste instituudi õppejõud \\ marit.koit@gmail.com
}

\begin{abstract}
Teesid: Artikkel koosneb kahest osast. Esimesest osast leitavad empiirilised andmed Eesti koolinoorte kohta seoses liiga valju ning erinevas stiilis muusika kuulamise ja vaikusetaluvusega kõnelevad identiteedi loomise eri teedest, aga ka ühiskonna vaimsest tervisest. Muusika kuulamise ja kuulmise probleemiga ühenduses ilmnevad paradoksaalsed seosed inimese, kuulatava muusika ja maailma vahel. Vastused, miks paradoksaalsus ilmneb, leiab artikli teisest osast, kus eelkõige Martin Heideggeri keelefilosoofilisele mõtlemisele tuginedes vaadeldakse vaikimise ja vaikuse, valjuhäälse lobisemise, keele kui sellise ning inimese isenemise seoseid. Vastatakse küsimusele, miks kuulata muusikat ja vaikust.
\end{abstract}

Märksõnad: identiteet, isenemine, koolinoor, muusika kuulamine, lobisemine, vaikimine ja vaikus, vali muusika

\section{Sissejuhatus}

Muusika kuulamist ning improvisatsioonilist musitseerimist rakendatakse eesmärgipäraselt tervise säilitamiseks või parandamiseks ja ka haiguste või sisemise tasakaalutuse ennetamiseks muusikateraapias. Muusikaterapeut Alice Pehki (2010) sõnutsi kasutatakse muusikateraapiat stressiga toimetuleku parandamiseks, meeleolu- ja ärevushäirete ning psühhooside raviks, kriisiseisundite leevendamiseks, enesearendamiseks. Tervist edendavalt (või ka tervist pärssivalt) kasutatakse muusikat loomulikult ka väljaspool teraapiakonteksti. Samuti tervisekasvatust silmas pidades on viimastel aastatel hakatud ohtralt kõnelema vaikuseminutitest koolis (vt Vaikuseminutid), mis peaksid aitama lastel säilitada sisemist tasakaalu, häälestama neid keskendumisele hetkel tehtavate ülesannete juures. Kuna harjumuspärased viisid elada (käituda, 
õppida, suhelda, sisustada oma vaba aega ja puhata jm) hakkavad kujunema juba koolieas, siis pealkirjas esitatud küsimusele - miks kuulata muusikat ja vaikust? - on artiklis vastuseid otsitud eelkõige koolinoori silmas pidades.

Artikkel jaotub kahte suuremasse ossa. Juba esimese osa pealkiri annab osaliselt vastuse küsimusele, milleks kuulata muusikat. Kuulata selleks, et luua oma identiteeti. Identiteedi kujunemise teed muusika vahendusel võivad aga olla väga erinevad. Esimeses osas esitatavad empiirilised andmed koolinoorte liiga tugeva ning erinevas stiilis muusika kuulamise ja noorte vaikusetaluvuse kohta kõnelevad kõige muu kõrval laiemalt mõeldes ka meie ühiskonna vaimsest tervisest. Muusika kuulamise ja kuulmisega ühenduses ilmnevad paradoksaalsed seosed inimese, kuulatava muusika ja maailma vahel. Vastused, miks teatud paradoksaalsus ilmneb, leiab artikli teisest osast, kus eelkõige Martin Heideggeri keelefilosoofilisele mõtlemisele tuginedes vaadeldakse vaikimise ja vaikuse, lobisemise kui valjuhäälse kõnelemise, inimese isenemise ja keele kui sellise omavahelisi seoseid. Neist seoseviisidest tulenevalt tehakse järeldusi lobisemise ja vaikimise tähenduste kohta inimese elus. Vastuse leiavad ka näiteks järgmised konkreetsed küsimused: 1) Missugune on Eesti tänapäeva gümnaasiumiõpilaste ning põhikoolilõpetajate suhe vaikusse ja muusika kuulamisse kui tegevusse? 2) Missugune muusika soodustab vaikima õppimist? 3) Missugused on liiga valju muusika kuulamise tagajärjed?

\section{Muusika kuulamine noorte identiteediloomes}

Muusika tähenduslikkus inimese elus sõltub kolme komponendi omavahelistest interaktsioonidest. Muusika (mis tahes muusikastiil) ei eksisteeri lahus muusika kuulajast (ta personaalsetest kvaliteetidest) ja ümbritsevast sotsiaalkultuurilisest keskkonnast, kitsamalt mõeldes kuulamiskeskkonnast (vt nt North \& D. J. Hargreaves \& J. J. Hargreaves 2004: 41). Rudolf E. Radocy ja David Boyle (2003: 9) juhivad tähelepanu asjaolule, et funktsionaalset rolli inimese elus ei mängi mitte lihtsalt muusika, vaid just muusikaline kogemus. Seega noorena koolieas omandatud muusikakuulamise kogemused ja kogemus teatud viisil suhtuda muusikasse saavad määravaks edasise elu seisukohalt. Noorte puhul peetakse nende elus üheks olulisemaks muusika / muusikaliste kogemuste funktsiooniks personaalse identiteedi loomist. Muusika määravast rollist eneserefleksiooniprotsessis ning identiteedi konstrueerimises on kõnelnud kõik maailma silmapaistvamad muusikakuulamise uurijad (vrd Clayton 2009; DeNora 2000; Frith 1987, 1996, 2003; Hargreaves \& Miell \& MacDonald 2002; Laiho 2004; Simonett 2006; Sloboda \& Juslin 2001; Starr \& Waterman 2006). 
Näiteks Suvi Laiho (2004: 54-55) on noorukiea puhul eriti rõhutanud muusika olulisust suhetes ümbritsevate inimestega, tuues muusika funktsioonidega seoses esile interpersonaalsete suhete loomist. Tema sõnul on noorukieas suureks väljakutseks üheltpoolt oma vanematest eraldumine, teisalt aga muude oluliste suhete rajamine. Seega ilmneb konfliktne vajadus üheltpoolt eralduda, saavutada isolatsioon, teisalt aga vajadus kuuluda, saavutada lähedus. Muusika kujuneb siin tasakaalustavaks vahendiks, kuna sellel on Laiho väitel võime esile kutsuda ühtsuse ja kuuluvuse tundeid. Kollektiivsete emotsionaalsete kogemuste (koos kuulamine, koos laulmine) vahendusel võib inimene tunda sügavat kaasahaaratust ning seotust teistega. Seega muusika võimendab noorukieas sotsiaalseid kommunikatsioone ja kaaslasterühmaga identifitseerumist. Muusikalise identiteedi kujunemisel omabki olulist tähtsust just grupp, kuhu kuulutakse (vt ka Binas 2000; Selfhout et al. 2008).

Noored näevad muusikas ka võimalust väljendada oma opositsiooni täiskasvanukultuurile, mässata autoriteedi vastu ja vabaneda piirangutest. Muusika on noortele sel juhul vahendiks personaalsete muusikaliste eelistuste ja iseseisvusele viivate tegevuste otsingutel. Muusikas peitub võimalus reflekteerida iseend ja oma identiteeti (Laiho 2004: 55; vt ka Selfhout et al. 2008). Mark Tarrant, Adrian C. North ja David J. Hargraves (2002: 139) väidavad, et mistahes muusika meeldivuse põhjuseks ongi noorte puhul see, kas antud muusika aitab või ei aita kujundada positiivseid sotsiaalseid identiteete. Nii saab muusikast silt või identifikatsiooni märk, mille alusel hinnatakse teiste inimeste tõenäolist kuuluvust teatud gruppi (vt ka Binas 2000; Frith 1987) Erinevad muusikastiilid ja nendega kokkukuuluvad grupid annavad noorele võimaluse kogeda ning tundma õppida erinevaid identiteete, mille alusel luua oma minapilt. Omaette küsimuseks jääb, kas identiteedi teatud aspektid võetakse omaks rühma survel või isiklikust vajadusest ja otsustusest lähtudes.

Muusika ja identiteedi seoste üle on põhjalikult mõelnud Tia DeNora (2000; 2006), esitades erinevaid võimalusi, kuidas muusika inimest tema identiteedi "töö" juures aitab. Tema järgi aitab muusika inimestel meenutada, kes nad olid mingil teatud ajahetkel, ning näha end tol hetkel eksisteerinud esteetilise subjektina. Muusika abil taasloob inimene möödunud kogemuse (tavaliselt hõlmab see inimesi, sündmusi või tegevuspaiku) ning ka selle, kes ta ise tol hetkel selles kontekstis oli - s.t toimub retrospektsioon, mis omakorda on projektsiooniks tulevikku ja osutab, kuidas edasi minna. Nii on muusikaliselt esile manatud minevik allikaks refleksiivsele liikumisele olevikust tulevikku (DeNora 2006: 143). Loomulikult ei teki selline nn muusikaline "mälu või mäletamine" DeNora hinnangul mis tahes situatsioonis. Kõrgendatud momendi, "selle õige hetke" loomine sõltub paljude aspektide kokkusobivusest: osalevad inimesed, situatsiooni "õigena" tajumine, sotsiaalsed suhted, ümbruse või keskkonna 
struktuur, muusika ning inimene ise oma tunnete, soovide ja tujudega (samas: 144). Oluliseks osutub kõigi elementide ühtesulamine ja muusikasse "salvestamine". Kuna minevikus aitas muusika teatud situatsiooni konstrueerida, siis pakub see ka olevikus parameetreid, mille abil kogemust uuesti läbi elada. DeNora (2006: 145-146) sõnul on võimalik eneseleidmine muusika vahendusel. Inimesed "leiavad end" muusikalistes struktuurides nende aspektide kaudu, mida iseenda juures tajutakse ja väärtustatakse ehk inimene samastab ennast "oma" muusikaga.

Nimetatud aspekti rõhutab ka Briti sotsiomusikoloog Simon Frith (1987: 143), väites, et näiteks popmuusika on midagi sellist, mida inimene omab ja hoiab justkui enda valduses. Inimese lemmikmuusika on talle nii tähtis, et see on saanud osaks tema identiteedist ja enesemõistmisest. Kritiseerida muusikat või esitajat tähendaks kritiseerida ka kuulajat ennast. Igapäevases "identiteeditöös" kasutatakse muusikat enesetajumise peeglina, leides end armastatud muusika struktuurides "elus olevana” (DeNora 2006: 146).

Muusika identiteetiloov funktsioon on seda edukam, mida enam on kuulajal isiklikult kuulatava muusika üle kontrolli- ja otsustusvõimalusi. Just tänu salvestustehnoloogiatele on inimese ümber võimalikuks saanud helimaastik, kust muusika peaaegu kunagi ei puudu - s.t loodud on muusika kõikjalolemise fenomen. Plahvatuslikult on suurenenud tahtmatu ehk nn sunniviisiline muusika kuulamine. Muusika kõikjalolek tähendab, et kuulatav muusika ei ole alati enam meie endi kontrolli all ega juhtida, ning see omakorda on loonud võimaluse, et muusika võib olla ka midagi soovimatut, pealetükkivat või lausa ebameeldivat. Sellega seostub muusika võib-olla kõige olulisem tänapäevane funktsioon - muusika kõlamine taustaks mis tahes tegevusele, muusika võime ja võim kontrollida keskkonda. Sotsiomusikoloog Simon Frith (2003: 93) nimetab muusikat tänapäeva ühiskonnas koguni müra võrdkujuks. Otsida tulevat nüüd hoopis, mis ja kus on vaikus. Muusika taustafunktsiooni rõhutab ka psühholoog John Sloboda (2009: 437), selgitades, et muusikat valitakse üha enam saateks igasugustele muusikaga otseselt mitteseotud tegevustele (nt igapäevased üksildast laadi kodutööd jm). Ka Adrian C. North toob koos David ja Jon Hargreavesiga (2004: 71-72) oma uurimistulemustes esile, et inimesed kasutavad muusikat sageli "helilise tapeedina" ehk mittenõudliku taustana (vrd ka Schramm \& Vorderer 2002). Seega on muusikal üha enam täita õhkkonna ja atmosfääri loomise funktsioon, mida tänapäeval laialdaselt kasutataksegi ka kõikvõimalikes avalikes kohtades ja teenindusasutustes. Muusika ühe ülesandena nimetab Tia DeNora (2000: 58-60) teiste helide blokeerimist millelegi parema keskendumise nimel. Muusika aitab luua vastavat keskkonda ja kontsentreeruda, et inimene saaks rahus näiteks vaimset tööd teha. Seega kasutatakse muusikat, loomaks töötamise esteetilist keskkonda. Ka Sloboda 
(2009: 433) rõhutab muusika olulisust vaimse töö soodustamisel, lisades, et muusikat kasutatakse edukalt ka kontorites, parandamaks keskendumisvõimet, tõstmaks töökeskkonna kvaliteeti ning vähendamaks stressi.

Muusikalised kogemused teostuvad tänu muusika kuulamisele, mis on muusika kogemise juures esmase tähtsusega. Kõik eelnevalt kirjeldatud fenomenid saavad võimalikuks läbi kuulamise või kuulmise. Muusika kuulamise tähtsuse rõhutamiseks kasutab iiri musikoloog Paul Hegarty (2007: 197) filosoof Martin Heideggeri mõtet teosest "Sein und Zeit", et inimene on kaotanud end ümbritsevate inimeste hulka, nende teiste juttudesse, lobisemisse ega kuule enam iseennast. Hegarty rõhutab, et kuulmine ei teostu ainult kõrvas, vaid kogu kehas ja iseäranis ajus, mistõttu ongi oluline jagada heli tajumine kuulmiseks ja kuulamiseks (vrd ka Jourdain 2002: 249). Kuulmine on Hegarty sõnul heli lihtne tajumine, kuulamine aga refleksiivne teadvustatud kuulmine. Inimesel on võimalik selekteerida, missugustele helidele ta tähelepanu pöörab ja mida tõrjub.

Saksa muusikateadlane Klaus-Ernst Behne (1997: 147) on eristanud üheksa kuulamisstiili, mis kujunevad läbi kogemuse, mil muusika on inimese tähelepanu keskpunktis ja kuulaja mitte ainult ei kuule, vaid just kuulab ja hindab muusikat. Esitatud üheksa stiili on järgmised:

1) kompenseeriv stiil, kui muusika muudab kuulaja tuju või enesetunnet, psüühilist seisundit;

2) kontsentreeritud stiil, kui kuulaja keskendub ainult muusikale ja selle elementidele;

3) emotsionaalne stiil, kui muusikas leitakse tundeid ja tekivad emotsionaalsed reageeringud muusikale;

4) distantseeriv stiil, kui kuulaja püüab identifitseerida muusikalisele stiilile omaseid jooni, mõista sõnu, järgida ühe instrumendi liini, tabada teose struktuuri;

5) vegetatiivne stiil, kui muusika avaldab mõju kehale ja füsioloogiale;

6) sentimentaalne stiil, kui muusika kutsub kuulajal esile unistused, mälestused, endast mõtlemise;

7) assotsiatiivne stiil, kui kuulajal tekivad pildilised kujutlused, luuakse jutustus nagu filmis;

8) stimuleeriv stiil, kui muusika ergutab nt valju muusika kuulamisel;

9) hajutav stiil, kui kuulaja tähelepanu on muutuv ning kuulamise ajal tegeldakse muude asjadega.

Nagu näeme, ühendavad erinevad kuulamisviisid nii muusikasiseseid kui ka -väliseid aspekte. 
Järgnevates alaosades 1.1 ja 1.2 on esitatud andmed Eesti koolinoorte muusika kuulamise kohta, mis pärinevad kahest meie endi sisult lähedasest empiirilisest uurimusest.

\subsection{Valju muusika kuulamisest}

Airi Liimets ja Kerli Hanni (tollane Eesti Muusika- ja Teatriakadeemia magistrant) viisid 2008. aasta kevadel läbi empiirilise uurimistöö, mille eesmärk oli välja selgitada, missugust ja kui tugevat muusikat noored igapäevaselt kuulavad. On ju argikogemustest teada, et noored armastavad sageli kuulata muusikat lausa kuulmist kahjustavalt valjult. Uurimistööga üritatigi teada saada, kas antud asjaolu leiab kinnitust. Empiiriliste andmete kogumismeetodiks oli kinniste ja lahtiste küsimustega küsitluskava, mille koostasime ise. Uuritavateks olid kokku 220 põhikooli lõpuklassi ehk üheksandate klasside õpilast (vanuses 14-16 aastat) viiest Eesti koolist (kolm Tallinnast ja kaks Harjumaalt). Poisse oli uuritute hulgas 114 ning tüdrukuid 106. Kuna andmete analüüs olulisi soolisi erinevusi esile ei toonud, siis allpool eraldi poisse ja tüdrukuid ei vaadelda.

Selgus, et muusika kuulamine kui tegevus oli nende noorte seas igapäevaselt väga populaarne. Väga meeldis muusikat kuulata 85 protsendile küsitletutest ning küllaltki palju meeldis see 15 protsendile. Kõige populaarsemaks muusika kuulamise põhjuseks osutus muusika rahustav, lõõgastav toime, mis väideti mõjuvat emotsioonidele (41\%). Paljud küsitletutest (35\%) kuulavad muusikat ajaviiteks ehk igavuse peletamiseks. Kolmanda põhjusena nimetasid aga õpilased (14\%), et muusika aitab neil vaikust peletada. Öeldi, et vaikus häirib; et muusika peab mängima, sest see viib reaalsest maailmast eemale ning aitab põgeneda tegelikkuse eest, laseb viibida nn oma maailmas. Neljanda muusikakuulamise põhjusena nimetas $10 \%$ õpilastest, et hea on muusikat ise teha ja seda siis teistele kuulata pakkuda ning läbi muusika tegemise iseennast paremini tunda õppida ja teostada. Viimasel juhul oli tegemist muusikat põhjalikumalt õppivate noortega.

Missugust muusikastiili ja kus noored kõige enam kuulavad? Esikohale asetus rock-muusika (52\%), teisele kohale popmuusika (27\%), kolmandale kohale metal ja drum'n'bass (10\%), neljandale kohale hip-hop (9\%). Vastanutest $91 \%$ väitis kuulavat muusikat eelistatult omaette kodus. Seda võib tõlgendada ka kui võimalikku ilmingut kapseldumisest ja eraldumisest, sest veel kümme aastat varem, 1998. aastal (samuti aastail 1975, 1979, 1984 ja 1994) Eestis mahuka õpilaste elustiiliuurimuse raames kogutud empiirilised andmed kinnitasid, et noored kuulavad muusikat valdavalt koos olles ühiselt mingi muu tegevuse 
taustaks. Ehk siis noorte muusikakuulamine oli aastakümneid olnud sotsiaalne ja suhete loomisega kaasnev tegevus.

\begin{tabular}{|l|l|l|l|l|}
\hline & $\begin{array}{l}\text { Täiesti eba- } \\
\text { oluline (\%) }\end{array}$ & $\begin{array}{l}\text { Küllaltki eba- } \\
\text { oluline }(\%)\end{array}$ & $\begin{array}{l}\text { Küllaltki } \\
\text { oluline }(\%)\end{array}$ & $\begin{array}{l}\text { Väga oluline } \\
(\%)\end{array}$ \\
\hline Muusikastiil & 7 & 20 & 54 & 19 \\
\hline $\begin{array}{l}\text { Muusika ilus } \\
\text { kõla ehk tämber }\end{array}$ & 1 & 21 & 53 & 25 \\
\hline Meloodia & 4 & 13 & 47 & 36 \\
\hline Harmoonia & 15 & 37 & 34 & 14 \\
\hline $\begin{array}{l}\text { Muusika päritolu } \\
\text { (kodumaine või } \\
\text { välismaine) }\end{array}$ & 56 & 27 & 10 & 7 \\
\hline $\begin{array}{l}\text { Muusika } \\
\text { agressiivsus }\end{array}$ & 19 & 38 & 31 & 12 \\
\hline Sõnad ja tekst & 6 & 13 & 45 & 36 \\
\hline Rütm & 2 & 9 & 50 & 39 \\
\hline Muusika tugevus & 0 & 25 & 46 & 29 \\
\hline
\end{tabular}

Tabel 1. Olulisim aspekt kuulatavas muusikas.

Mida tajuti muusikas selle tähtsaimate aspektidena ehk missugust muusikat pidasid noored heaks muusikaks? Küsimusele antud vastuste protsendijaotused on näha tabelis 1. Muusika tugevust muusikalise väljendusvahendina pidas väga oluliseks $29 \%$ ning küllaltki oluliseks $46 \%$. Seega oli muusika tugevus oluline kvaliteet 75 protsendile vastanutest. Küllaltki ebaoluliseks pidas muusika tugevust $25 \%$ õpilastest ning täiesti ebaolulisena ei nimetanud seda mitte keegi. Kui liita muusika väljenduslikke tunnusjooni väga oluliseks ja küllaltki oluliseks hinnanud inimeste hulgad, siis asetub muusika valjus küll alles viiendale kohale. Esikohal on rütm, järgnevad meloodia, sõnad ja tekst, tämber ning seejärel tuleb tugevus. Sõnad ja tekst on muusikat põhjalikumalt mitteõppinud inimestele ilmselt kõige lähedasem aspekt muidu puhthelilises koosluses. Siinkohal olgu nimetatud mõned ilmekamad õpilaste väited selle kohta, mida hea muusika kindlasti endas sisaldama peaks:

Hea muusika on see, kui käib äge raiumine nii, et kuulates enda rääkimist ei kuule.

Minu arvates on hea muusika see, kus on palju tümmi.

Mulle meeldib nn "vaiba kloppimine" ja suht väheste sõnadega laulud.

Kus on sõnad ja millest ma saan aru, mitte, kus on ainult mingi tümps.

Hea muusika on see, mis jääb kergesti meelde ning loob hea meeleolu. 
Missuguse tugevusega muusikat noored tavaliselt kuulavad? Ülitugevat muusikat soovib kuulata 14\% õpilastest, tugevat muusikat 45\%, keskmise tugevusega $36 \%$, suhteliselt vaikset muusikat $5 \%$. Väga vaikset muusikat ei soovi ega taha noortest aga keegi kuulata. Ülivalju muusika kuulamise põhjenduseks väideti, et see on kaif, saan tugeva emotsiooni, olen omas maailmas. Valju muusika kuulamise põhjendus: Tümps on hea, siis teised helid ei sega. Keskmise tugevusega muusika põhjenduseks: Liiga tugev heli tekitab peavalu, aga vaikselt ka ei kuule. Suhteliselt vaikse muusika kuulamise põhjendus: Olen kuulnud, et tugev muusika rikub kuulmist; Liiga tugev muusika tekitab peavalu ja paneb kõrvad undama.

Kui kaua päevas noored suudavad või tahavad kuulata tugevat muusikat? Vastusevariandi "üldse ei suuda" valis $2 \%$ ning "kuni veerand tundi" valis $9 \%$. Pool tundi kuni tund kuulab päevas tugevat muusikat $19 \%$ küsitletutest, tund kuni kaks kuulab 25\%, kaks kuni kolm tundi 20\% ning veelgi kauem kui kolm tundi $25 \%$ õpilastest. Kõige enam meeldib külastada rock-muusika kontserte $(67 \%)$, regulaarseid diskokülastajaid on noorte seas $21 \%$. See tähendab, et ollakse vägagi ohustatud liigsetest detsibellidest, sest rock-muusika kontserdi detsibellid küündivad kuni 140 dB-ni. Inimese kuulmise valulävi on aga 120 dB ning üle selle on kõik kahjulik ning ohustab tervist (vrd Sundberg 1995: 51). $54 \%$ noortest viibivad sellistel üritustel keskmiselt kolm ja rohkemgi korda kuus. Vaid $8 \%$ küsitletud õpilastest nimetas, et nad käivad mõnikord ka kiriku- või klassikakontsertidel. Järeldada võib, et need viimased ei paku noortele huvi. Tabelist 2 võib lugeda, kuidas tuntakse ennast pärast tundide-pikkust viibimist tugevas heliväljas.

\begin{tabular}{|l|l|l|l|l|}
\hline & $\begin{array}{l}\text { Mitte kunagi } \\
(\%)\end{array}$ & Harva (\%) & Sageli (\%) & $\begin{array}{l}\text { Väga sageli } \\
(\%)\end{array}$ \\
\hline Kõrvus kohiseb & 27 & 43 & 25 & 5 \\
\hline Olen väsinud & 25 & 49 & 24 & 2 \\
\hline Olen energiline & 8 & 24 & 48 & 20 \\
\hline Olen puhanud & 29 & 42 & 23 & 6 \\
\hline Olen närviline & 65 & 25 & 7 & 3 \\
\hline Olen heas tujus & 4 & 13 & 40 & 43 \\
\hline Olen kurnatud & 41 & 41 & 15 & 3 \\
\hline $\begin{array}{l}\text { Ei suuda selgelt } \\
\text { mõelda }\end{array}$ & 57 & 31 & 10 & 2 \\
\hline $\begin{array}{l}\text { Muu (peavalu, } \\
\text { kõrvavalu jm) }\end{array}$ & 0 & 0 & 32 & 68 \\
\hline
\end{tabular}

Tabel 2. Mida tuntakse pärast mitmeid tunde tugevas heliväljas viibimist? 
Nagu näha, toimib tugev muusika noortele valdavalt stimuleerivalt, nagu ka eespool juba nimetatud Klaus-Ernst Behne (1997: 147) seoses kuulamisstiilidega esile tõi. Kui liita andmed rubriikidest väga sageli ja sageli, siis pärast pikaajalist viibimist valju muusika mõjuväljas ollakse väidetavalt energiline ja heas tujus. Samas ei saa jätta tähelepanuta, et tabeli viimase rea arvudega tehtav liitmistehe võimaldab öelda, et $100 \%$ küsitletutest tunneb valju muusika kuulamise järgselt mingit valu. Järelikult ollakse vägagi ohustatud tugevatest detsibellidest, kuid seda endale eriti ei teadvustata. Puhanuna tunneb end antud situatsioonis vaid $29 \%$ küsitletud õpilastest. Seega paljudele tugev muusika siiski hästi ei mõju, vaid vastupidi - mõjub väsitavalt. Hea tuju ja energilisuse võib tugeva muusika kuulamisest ju saada, kuid vaevalt seeläbi küll rahu leitakse, mida nimetas üldse muusika kuulamise peamise põhjusena ju $41 \%$ noortest, nagu eespool juba öeldud.

Kõrvaarstid puutuvad tänapäeval kokku järjest sagedamini noorukitega, kes on pärast rock-kontserti või oma meelismuusika mitmetunnist meeletu helitugevusega kaifimist kuulmise osaliselt või täielikult kaotanud. Tänapäeva noorel nn kõrvaklapipõlvkonnal arvatakse kuulmine 40aastaselt olevat sama halb kui praegustel 70aastastel (Pedusaar \& Müürsepp \& Vabamäe 2001: 12). Seega väga valju ja valju muusika kuulamine on lausa meditsiiniline probleem. Tänapäeval ümbritseb inimest kõikjal ja vahetpidamatult ka olmemüra, nii et pöördumatute kuulmiskahjustustega inimesi on aina rohkem. Ohustatud on ka vaimne tervis. Sisemist stressi püütakse valju muusika abil "surnuks" tampida, et saada hakkama elamisviisiga, mille puhul olulisel kohal on müra, kiirus, pidev askeldamine. Nagu Vaike Sarv (2002: 32) vahendab, on akustilise ökoloogia uurijate (nt Barry Truax, R. Murray Schafer jt) arvates siin tegemist teadvustamata hirmuga oma allasurutud tunnete ees, mida pole tahetud või osatud läbi töötada. Appi võetaksegi kuulamisaparaadid, mis aitavad tegelikkuse eest põgeneda. Valju muusika kuulamisega end argipäevast välja lülitavad noored riskivad aga saada "kõva" kuulmise.

Seega liiga valju muusika kuulamine ning elamine pidevas mürakeskkonnas kahjustab inimest nii füüsilises kui vaimses mõttes. Küllap seetõttu ongi ühiskonnas viimastel aegadel üha enam hakatud rääkima vaikusest ja vaikimisest, vaikusetaluvusest.

\subsection{Vaikusetaluvuse ja muusika kuulamise seostest}

Allpool esitatavad järeldused Eesti noorte vaikusetaluvuse ja muusika kuulamise seoste kohta on selgunud Airi Liimetsa ja Marit Koiti ühise empiirilise uurimistöö raames aastail 2010-2011 kogutud andmestiku analüüsidest. Nimetatud uurimuses osales 909 küsitletavat, kes olid 11. klasside õpilased (vanuses 
17-18 aastat) Eestimaa kümnest maakonnast ning 24 gümnaasiumist. Uuritute hulgas oli poisse 416 ehk 45,9\% ning tüdrukuid 491 ehk 54,1\%. Andmete analüüs olulisi soolisi erinevusi esile ei toonud. Andmete kogumismeetodiks oli kinniste ja lahtiste küsimustega küsitluskava "Pingist pinki", mille koostasid Airi Liimets, Jüri Kruusvall ja Marit Koit (2009). Andmed analüüsiti SPSSprogrammi versiooni 14.0 abil.

Antud uurimuse kohaselt on muusika kuulamine noorte vaba aja tegevuste hulgas kindlalt esimesel kohal: iga päev kuulab muusikat 82,3\% noortest, nädalas mitmed korrad kuulajaid oli lisaks veel 13,95\%. Noorte endi väitel on nende identiteet ja muusika omavahel väga tihedalt seotud, nagu kinnitasid ka mitmed eespool viidatud muusika kuulamist uurivad teoreetikud. Meie uurimuse 909 küsitletust 6,8\% leidis, et minu 'mina' - see ongi mu muusikaeelistused; 70,5\% silmis oli muusika üks väga oluline osa tema 'minast'; $18,5 \%$ leidis, et muusika on suhteliselt vähetähtis; ning üksnes $3,1 \%$ vastas, et muusikal pole tema 'minaga' mingit pistmist ( $1,1 \%$ noortest jättis sellele küsimusele vastamata).

Tehtud korrelatsioonanalüüs näitas, missuguste muusikaliste, isiksuslike ning inimese elustiili kui tervikut väljendavate kvaliteetidega seostub vaikusetaluvus ja -lembus. Statistiliselt olulisel nivool $(a=0,05)$ korrelatiivsed seosed erinevate tunnuste vahel kinnitasid, et inimesed, kellele meeldib vaikus ja kes otsivad vaikust, need:

1) peavad end vabadeks inimesteks $(r=0,41 ; \mathrm{p}<0,05)$;

2) ei kuula ülitugevat muusikat ( $\mathrm{r}=0,45 ; \mathrm{p}<0,05)$;

3) kuulavad eelkõige klassikalist muusikat $(\mathrm{r}=0,36$; $\mathrm{p}<0,05)$;

4) musitseerivad ka ise ( $r=0,32 ; \mathrm{p}<0,05)$;

5) soovivad sageli olla omaette üksinda ning neil on kodus oma tuba ( $\mathrm{r}=0,31$; $\mathrm{p}<0,05)$;

6) elavad kultuurilembeses kodus - s.t neil on kodus palju raamatuid, oma vanematega vesteldakse tihti ka kultuuriteemadel $(\mathrm{r}=0,34 ; \mathrm{p}<0,05)$.

Küsimusele, kas nad pigem teavad või tunnevad, et nad üldse on olemas, vastasid need inimesed, et nad eelkõige tunnevad seda. Antud vastust võib pidada käesolevas kontekstis kõnekaks mitmel põhjusel. Just tunne (ja mitte teadmine) oma maailmasolemisest ehk mina-tunne väljendab inimese ihulisuse, olevikulise somaatilise tundlikkuse ning ruumis liikumisega seonduvat eneseteadvuse algseimat vormi (vrd nt Bermúdez 1998; Thibault 2000; Gerhardt 1999). Paul J. Thibault' (2000: 302) järgi on helid, mida inimene näiteks kõneldes ise tekitab, vahetult seotud ta ihutundega. Inimese keelelis-kultuuriline identsus juurdub ta aistingulises tunnetuses. Siit edasi mõeldes võib järelikult nõustuda juba eespool viidatud muusikakuulamise uurija Paul Hegartyga (2007: 197), kes rõhutab, et kuulmine leiab aset kogu kehas, mistõttu ongi mõttekas 
jagada heli tajumine kuulmiseks ja kuulamiseks. Kuulmine on Hegarty sõnul heli lihtne tajumine. Siit võib järeldada, et noorte puhul, kes väidavad, et nende muusikaeelistused on nende 'mina' või väga suur osa nende 'minast', ongi pigem tegemist muusika kuuljatega, mitte kuulajatega. Võimalik, et kogu ihu hõlmava kuulmise kui fenomeniga on seotud ka inimese soov vaikida ja vaikusetaluvus, miks muidu seostub see oma personaalse ruumi (kodus oma toa) olemasoluga, sooviga tõmbuda üksindusse ning vabadusega olla 'mina ise'. Sealjuures tuleb silmas pidada, et kõige esmasem nn omaruum, privaatseim "kodu" ongi inimesele ta oma ihu. Eneseteadvuse uurija Jose Luis Bermúdez (1998: 134) ütlebki, et inimese maailmasolemise kogemus on sünnipäraselt eelkõige ruumiline, selle esmaseks piiriks on ihulisus. Seega kuulmise kaudu ihulise omaruumi piiritlemine seostub eneseteadvusega.

Missuguse muusikastiili kuulamine/kuulmine (lisaks klassikalisele muusikale) soodustab kõige enam liikumist vaikusse ja iseenda omaruumi poole? Sellele küsimusele vastame samuti meie endi 2010. ja 2011. aasta empiirilise uurimuse andmetele tuginedes.

Korrelatsioonanalüüsi põhjal võib väita, et omaette rühma kokkukuuluvaid muusikastiile moodustavad klassikaline, jazz- ja pärimusmuusika; teist selget rühma piiritlevad pop- ja tantsumuusika. Rock-muusikat võib pidada kolmandaks, nn piirirühmaks, sest sel on seoseid nii esimese kui ka teise nimetatud rühmaga, kuid rohkem esimesega. Kuidas eri muusikastiilide eelistus seondub inimest kui tervikut ja ta elustiili väljendavate tunnustega, sellest annavad tunnistust korrelatsioonidevõrgustike kujul moodustunud kolm konfiguratsiooni, mille põhjal võibki järeldada, missuguste muusikastiilide kuulamine/kuulmine soodustab või takistab inimesel teatud kvaliteetide kujunemist. Sealjuures tuleb silmas pidada, et konfiguratsiooni kui sellise näol on tegemist pidevas liikumises ja muutumises olevate tunnustekogumiga, mitte kindlapiiriliste ning staatiliste klasteranalüüsi abil väljaselgitatud tüüpidega. See aga tähendab, et piirid eri konfiguratsioonide vahel pole kuigi teravad. Näiteks teatud situatsioonides võib üks konkreetne inimene osutuda kuuluvaks ühte konfiguratsiooni, teistel juhtudel jälle teise. Kuulatakse ju ühtaegu paljudes stiilides muusikat. Oluline on aga see, missugused kvaliteedid on kellegi puhul domineerivamad ja missuguseid väärtusi enamasti järgitakse.

Meie koostatud küsitluskava "Pingist pinki" (2009) koolinoorte elustiili uurimiseks sisaldab 434 küsimust/tunnust. Olulisimad sisuplokid on järgmised: 1) väärtusmaailm, 2) muusikakäitumine ja -teadvus, 3) vaba aja käitumine, 4) isiksust iseloomustavad omadused, 5) tulevikuplaanid ja -ideaalid, 6) õppimine ja kool elustiilis, 7) (mitte)kuuluvus noortekultuuridesse, 8) kodust kasvukeskkonda iseloomustavad tunnused. Allpool kirjeldatud kolme konfiguratsiooni moodustanud tunnustena nimetame aga vaid need, mis korrelatsioonidevõrgus- 
tikes osutusid omavahel seotuks statistiliselt olulisel nivool $(a=0,05)$ olevate korrelatsioonikordajatega $(r)$, kui olulisustõenäosus $\mathrm{p}<0,05$. Tunnustevaheliste seoste tugevust väljendavate korrelatsioonikordajate väärtused kolme konfiguratsiooni piires ei ole väiksemad kui 0,22 ning mitte suuremad kui 0,48.

Muusikastiilidest pop- ja tantsumuusika eelistamine seondub järgmiste nähtustega: muusika kuulamise funktsiooniks on vältida üksindust ja suhelda, muusikat kuulatakse muude tegevuste taustaks ning muusikat ennast (s.t kui kunsti) üldse ei tähtsustata. Muusika peab aktiveerima liikumisele ja võimaldama füüsilist lõõgastust; eriti tantsumuusika eelistajad soovivad kuulata võimalikult valju muusikat, saada pidevalt meelelahutust. Popmuusika eelistajatel moodustab kuulatav muusika olulise osa nende 'minast'. Vaikuses olla neile inimestele ei meeldi ja vaikust ei taluta. Oma seisukohtade ja arusaamade peamiste kujunemisteguritena nimetatakse TV-d, suhtlemist internetis ning avaliku elu tegelasi, mitte isiklikku sündmuste analüüsi ja mõtestamist. Neile meeldib olla tähelepanu keskpunktis ja saada kiidetud. Väärtustemaailmas domineerib jõukusefaktor - oluliseks peetakse materiaalsust, tutvusi ja luksust, reisimist; soovitakse olla edukas ja saavutada elus juhtiv positsioon. Õpetajatega saadakse koolis halvasti läbi, hinnetest on ülekaalus "kolmed", kodus tehakse õppidaolevaid kodutöid minimaalselt. Kool on nende silmis ebameeldiv paik ning on kaalutud ka kooli poolelijätmist. Õppimine oleks nende meelest meeldivam, kui õpetajad täpselt ütleksid, mida teha tuleb, ja kui ise mõtlema ei peaks. Kooli ja õppimise vaenulikud on eriti tantsumuusika eelistajad. Kokkuvõtlikult üldistades võib öelda, et pop- ja tantsumuusika eelistajate näol on ilmselgelt tegemist kõigele iseendast välisele orienteeritud nn massija staatuseinimesega, kel puudub oma 'mina'. Sellest tulenevat tühjustunnet püütaksegi täita kõikvõimaliku suhtlemise ja sukeldumisega trendidesse ning edukuse- ja tarbimiskultusesse, tugevasse muusikasse.

Põhimõtteliselt vastanduvad eelkirjeldatutele jazz- ja pärimusmuusika ning klassikalise muusika eelistajad, samuti rock-muusika eelistajad, ehkki need moodustavad siiski omaette kolmanda nn piirirühma. "Rokkarid" torkavad eriliselt silma iseseisva mõtlemise ja tegutsemisaktiivsuse poolest. Koolis pole nad häid hindeid saavad õpilased, kuid pole ka otseselt koolivaenulikud, ehkki kool oma reeglitega ahistavat nende vabadust. Muusikas on neile eriti olulised sõnad ja jõulisus/tugevus. Samas pole tugeva muusika kuulamine nende silmis väärtus omaette, vaid see tuleneb kunstilistest taotlustest.

Muidu sarnanevad "rokkarid" põhijoontes klassikalise, jazz- ja pärimusmuusika eelistajatega, kelledele meeldib olla vaikuses, mis soodustab inimesel iseenda leidmist. Ise musitseerimine on neile väga oluline väärtus ning ollakse avatud ka igasugusele uuele muusikale. Väärtustest on neile täiesti ebaolulised kõik jõukuse, raha ning välise staatusega seonduv, oluliseks peetakse altruis- 
mi ja ausust, kultuuri kui sellist ning ollakse kultuuriliselt mitmekülgselt aktiivsed. Ollakse ka refleksiivsed mõtestajad: on mõeldud välja ise õpivõtteid, suudetakse teadvustada oma õpiajaloos teatud murdepunkte ning koolis saadakse ka häid hindeid. Kooli peetakse meeldivaks paigaks, edu õppimises seostatakse võimalusega iseseisvalt õppida. Muusika kuulamise funktsioonidest on olulisim, et see aitaks mõista iseennast ja oma mõtteid. Ka väidetakse oma arusaamad elust olevat kujunenud raamatute ning sündmuste isikliku analüüsi tulemusel. Nagu popmuusika puhul, väidavad ka need õpilased, et nende muusikaeelistused ongi nende 'mina' või oluline osa nende 'minast'.

Kokkuvõtteks võib öelda, et korrelatsioonanalüüs kui selline ei võimalda küll kindlalt väita, missugune fenomen nimelt mille kujunemist otseselt mõjutab, sest tegemist on vastastikuses sõltuvuses olevate keerukate komplekssete seostega. Küll aga võimaldab see seostevõrgustik saada ettekujutuse sisuliselt omavahel kokkukuuluvatest fenomenidest.

Kõigest esimeses osas kirjutatust võib järeldada, et tänu identiteeti loovale funktsioonile on muusika kuulamine ja kuulmine fenomenid, mis aitavad inimesel astuda ühendusse maailmaga, mida kas lubatakse oma privaatsesse sfääri või mitte. Ilmneb paradoksaalne suhe: mida enam tundub meil maailma olevat erinevate kommunikatsioonide, kõikjaloleva muusika kohalolu ja meelelahutuslikku popmuusikasse sulandumise näol, seda vähem seda tegelikult on, sest anonüümset massikultuuri esindav pop-muusika imbub küll kuulaja ihusse, kuid ei saa tema nn omaruumi koostisosaks, kuna on võõrandunud individuaalsusest kui sellisest; ehkki inimene ise arvab, et vastav muusika - see ongi tema ise. Popmuusika kuulaja küll kuulab seda, kuid ilmselt ei kuule, sest antud muusika anonüümsus on võimukas inimese suhtes, kes ei tunne ega õieti ka tea, et ta üldse maailmas olemas on. Muusika kuulamisprotsessi seisukohalt kolm olulist osapoolt (kuulaja, muusika ja välismaailm/kuulamissituatsioon) on pop- ja tantsumuusika vahendusel seotud illusoorsete sidemetega. Klassikalise, jazz- ja pärimusmuusika kuulaja aga tõenäoliselt nii kuulab kui ka kuuleb.

Millega seletada kuulamisprotsessi kolme komponendi vahel kirjeldatud vastuolulist, paradoksaalset suhet? Nimetatud küsimusele leiab vastuse artikli järgmisest ehk teisest osast.

\section{Miks kuulata vaikust?}

Muusika vahendusel inimese identiteedi kujunemise paradoksaalsus ja vastuolulisus on seletatav inimeseks olemise paradoksaalsusega. Inimese maailmasolemine on ühtaegu iseolemine ja koosolemine, nagu seda filosoofilisest vaatepunktist on 20. sajandil ehk kõige selgemini analüüsinud Martin Hei- 
degger eelkõige teoses "Sein und Zeit" (Olemine ja aeg) (vt Heidegger 1993). Inimese loomus juurdub keeles kui sellises. Maailm on inimese jaoks alati keeleliselt häälestatud (Heidegger 1996). Keelena võib käsitada aga mis tahes märgisüsteemi (s.h muusikat), kus märk tähistab ja kannab teatud tähendusi, mis mängivad inimeste elus mingit rolli. Keelelisuse kui sellise kaudu on omavahel tingimatult seotud valjuhäälne lobisemine, liiga valju muusika kuulamine, vaikimine ja vaikus ning inimese kui sellise isenemine ehk iseendaks saamine. Järgnevalt avame nimetatud fenomenide vaheliste seoste sisu, tuginedes Heideggeri keelefilosoofilisele mõtlemisele, ning kõige tulemusena leiabki vastuse ka küsimus, miks kuulata vaikust.

Martin Heideggeri loomingus oli keelefilosoofiline mõtlemine üks katkematult kulgevatest temaatilistest mõtteliinidest (vrd nt Stahlhut 1986; Xiropaidis 1991; Stassen 1973). Nn varase Heideggeri vastavad ideed leiduvad eelkõige ta 1927. aastal ilmunud teoses "Sein und Zeit". Selle ajajärguga seonduvalt kõneldakse Heideggeri Daseini keelest (die Sprache des Daseins). Aastail 1928-1947 mõtleb Heidegger keelest kui olemise keelest (die Sprache des Seins). Põhilisena võib siin nimetada 1946. aastast pärinevat teksti "Über den 'Humanismus" (Humanismist). Hilise Heideggeri (aastail 1949-1976) seisukohalt on keel käsitatav kui isenemise keel (die Sprache des Er-eignisses). Olulisima tekstina sellest ajajärgust saab nimetada esmakordselt 1959. aastal ilmunud artiklit "Der Weg zur Sprache" (Tee keele juurde). Heideggeri mõtlemine keelest kui isenemise keelest on artikli autori A. Liimetsa arusaama kohaselt tugevalt mõjustatud identiteedi ja diferentsi käsitlusest filosoofi 1957. aastal ilmunud teoses "Identität und Differenz". Heideggeri keelefilosoofia interpreteerijad ja uurijad Christian Stahlhut (1986), Manfred Stassen (1973) ja Georgios Xiropaidis (1991) pole huvitaval kombel sellele sõnagagi osutanud. Järgnevalt tugineme oma käsitluses valdavalt nn varasele Heideggerile ja ta mõtetele Dasein'i keelest.

\subsection{Valjuhäälsest lobisemisest ja vaikimisest}

Heidegger on teoses "Sein und Zeit" (1993) kirjeldanud inimese maailmasolemist teatud omaloodud mõistete ehk eksistentsiaalide abil. Eksistentsiaali Dasein võib käsitada inimest kui sellist väljendava mõistena. Daseini iseolemine (Selbstsein) ja isesus (Selbstheit) on alati ka koosolemine (Mitsein) kas teiste inimestega, asjadega või iseendaga. Väga oluliseks osutub eksistentsi seisukohalt viis, kuidas Dasein end ajas olemasolevaks teeb ehk end ajalisustab, s.t millelt lähtudes saab oma tähendused ja mõtte. Sama ideed artikli esimeses osas esitatud konfiguratsioone kirjeldavas sotsioloogilises keeles väljendades võib öelda, et oluline on, mida elus väärtustatakse (nt kas jõukust või eneseteostust, 
klassikalist või popmuusikat). Dasein'i olemiselt kui võimalikkuselt avaneb tema eksistents: a) kas oma tegelikku ehk päristist iseolemist (eigentliches Selbstsein) ehk isesust (Selbstheit) loovana, kui ajalisustatakse end eelkõige iseenda potentsiaalsusest ja loomusest lähtudes; b) oma mittetegelikku ehk mittepäristist iset (uneigentliches man selbst) loovana, kui enese ajalisustamise lähtealusteks on materiaalne rikkus, positsioon ja rollid institutsioonides ning soov sarnaneda teistele inimestele (olla nagu kõik teised) ning järgida ühiskonnas heakskiidetud trende.

Ühes konkreetses inimeses peituvad üheaegselt mõlemad nimetatud poolused - võimalus olla päristiselt ning luua oma iseolemist, ning olla mittepäristiselt ja toita oma mittetegelikku olemist. See, kumb neist ajalisustamisviisidest kellegi puhul domineerivamaks kujuneb, sõltub Dasein'i valikutest - kas olla olemas pigem ühel või teisel viisil. Seismist dilemma - kas see või teine - ees väljendabki ju ka saksakeelse sõna $D a$-sein (siin-, sealolemine, kohalolemine) semantika. Sellest tuleneb, et maailmas kohalolemiseks pole muud võimalust, kui olla ühtaegu nii siin kui seal, nii see kui teine, ning et tuleb teha valik, missuguse pooluse tähendus kujuneks määravamaks. Jaapani filosoof Kogaku Arifuku (1991: 153) ongi ka rõhutanud oma Heideggeri-interpretatsioonides päristise ise (Selbst) ning mittepäristise ise (man selbst) samapäritolulisust, illustreerides öeldut näitega jaapani kultuurist. Tema järgi peavad jaapanlased alati, enne kui millegi uuega võivad alustada, endale selgeks tegema ning mõtlema, kuidas teised ühiskonnas nende tegevust ja käitumist hinnata ja väärtustada võiksid. Seega man selbst on vaadeldav kui päristise ise nn antropoloogiline Teine, kui teatud kultuurikooslus, millega kuulutakse kokku, kuid millest end individuatsiooni käigus individualiseerumise läbi ometi eristatakse.

Dasein'i tema olla-oskamises iseloomustab Heideggeri (1993: § 29-35) järgi mõistmine, teatud meeleolu läbi häälestatus ja kõne. Kuna keel ja kõne loovad maailma, siis osutub oluliseks, missugust mõtet kõnelemine artikuleerib ja mis on teemaks, kuidas iseennast väljendatakse (missugune meeleolu kõnet saadab) ning kuidas ja mida teistele tahetakse teatada. Seos mõistmisega tuleb eriti ilmsiks kõne teatud liikide kaudu. Need on kuulamine ja kuulmine ning vaikimine. Suutlikkus vaikides kuulata ja kuulda kõnet tähistab koosolemises eksistentsiaalset teistele avatud olekut, mis on mõistmise eelduseks. Kui ei suudeta kuulata ega vaikida, on marieunderlikult (Under 1981: 183) väljendudes huulil vaid umbsõnad, kõik kõneldakse lõhki ja keegi ei mõista enam aru saada.

Nimetatud avatudolek puudub (ehk see on näiline) kõne ühe liigi - lobisemise (Gerede) (Heidegger 1993: § 35-38) - korral, mis iseloomustab mittetegelikku ehk mittepäristist iset ehk man selbst'i. Eksistentsiaaliga Man (tuletatud saksakeelsest umbisikulisust väljendavast partiklist man) tähistas Heidegger umbisikulist massiinimest, kes kunagi pole tegelikult tema ise ja keda võib 
iga hetk kestahes teisega asendada. Man - see on stereotüüpne inimene, kes on lahustunud kommunikatsioonide impersonaalsuses ja keda täidab pidevalt vajadus lobiseda, et luua endale illusioon oma elu tõelikkusest, aimamata, et tegelikult koob ta oma lobaga enese ümber üha tihedamat näilikkuse võrku. Lobisev inimene - see on Dasein oma argisuses (nn langenud inimene). Antud fenomen rajaneb teistega sarnane olemisel. Kõike kõneldavat mõistetakse kui läbilõikelist, kui kõigile kuuluvat. Kõneldakse nn anonüümset, sisuliselt mitte midagi tähendavat keelt. Keel ongi põhiline vahend, mille abil võimukas man selbst kindlustab endale inimeses võimu päristise ise üle. Gerede on kõnelemine, kus keegi enam ei tea, mis on öeldust ehtne või mis uus, sest ka see, mis kuulutatakse olevat uus, on tegelikult sama vana ja tuttav, nagu kogu muu kõneldav loba. Kujuneb keele kahe- ning mitmetähenduslikkus, kus ringlevad vaid näivad tähendused, mistõttu see kõne kedagi sisemiselt ka ei puuduta. Räägitakse üksnes sellest, mida juba teatakse, mida seetõttu silmapilkselt arvatakse ka mõistvat, mis kõik mõjub mittepäristisele ise'le turvaliselt ja koduselt. Kõneldav ei tekita kartust ega hirmu, eneseväljendamine polegi oodatud ega võimalik. Stereotüüpne keel süvendab inimeses ta loomuse manilikku poolust. Sel inimesel polegi rangelt võttes iseennast, on vaid anonüümsed "võõrad" mõtted ja sõnad - samad, mis kõigil teistel. Nimelt sellisena võib käsitada ka meelelahutuslikku massikultuuri esindavat popmuusikat kui keelt ning selle kuulamist liiga valjult vastava muusika austajate poolt, kes ise arvavad, et see muusika ongi nende 'mina', aimamata, et selline muusikaline anonüümne keel neid iseenda individuaalsusest üha enam võõrandab.

Heidegger (1993: §40-41, 68) näeb väljapääsu ümbritsevatest lobisevatest inimestest ja oma loomuses mittepäristise ise võimukusest inimese iseenda poole liikumises, isenemises ehk iseendaks saamises, mille sisuks on pidev iseendast-ette-olemine, enesesünnitamine, oma piiridest väljumine, projitseeritus tulevikku, oskamaks olla nii, et jõuda oleva olemise mõistmiseni.

Ühe võimaliku vastuse küsimusele, kuidas jõuda oleva olemise mõistmiseni, leiab nn hilise Heideggeri (1997: 260-261) mõtetest, mille järgi inimese isenemine saab toimuda katkematu protsessina üksnes keeles ja keele kaudu, kui inimene on olemisele kui sellisele avatud; kui ollakse kuuldel keele poolt väljendatava varjamatusse toomise (kr. k. alētheia, tõlkes: varjamatus, ka tõde) suhtes. Need kuuljad/kuulajad saame aga olla vaid niivõrd, kuivõrd kuulume ise kuuldavale toodavasse. Teoses "Identität und Differenz" ütleb Heidegger (1996: 24-27) selgelt, et isenemine (Er-eignis; vanemas saksa keeles "er-äugen") kutsub inimese ja olemise neile loomupärasesse kokkuolemisse (Er-eignis vereignet Mensch und Sein in ihr wesenhaftes Zusammen).

Valjukõnelist, argielulist, manilikku Dasein’i kutsub Heideggeri (1993: §56-58) järgi iseendaks saama ta südametunnistuse kutse, mis hüüab vai- 
kides. See kutse katkestab inimeses man selbst'i kõne ning anub vaikides, et kuulataks oma päristist iset. Südametunnistus kutsub üksindusse, mis on täidetud ebamäärasest hirmust iseenda olemise pärast, mis on ka olemine surma poole. Tekkiv hirm laseb kokku kukkuda Mani valjuhäälsete kõneluste loodud iseenesestmõistetavana tunduval turvatundel, mis juurdub eelkõige keeles. Jäädes kuulama vaikivat südametunnistuse kutset, kogeb Dasein selles oma eimiskisust. Sellest surmateadlikust avatudolekust iseendaks olemisele ja oma südametunnistusele kasvab välja avatus teistele inimestele ja maailmale kui sellisele, nende kuulamisele/kuulmisele ja vaikimisele, milleks man selbst pole suuteline. Man kuuleb vaid stereotüüpset lobisemist, kuni teda tabav südametunnistuse vaikiv kutse pole suutnud seda katkestada.

Keel, eriti kui seda liiga palju ja mõttetult pruukida, nagu see iseloomustab Man-inimest, hakkab käsutama ja saavutab võimu inimeste üle. Võimukas keel surub meile peale nn võõrad sõnad (vrd ka Foucault 2005), mis võimaldabki öelda, et inimene pole mitte iseenda, vaid oma anonüümse diskursuse (nt erakonna ja partei, ametirolli vms) nägu. Iseendaks saada, teha valik oma päristise "ise" avardumise kasuks, end taas ja taas uuesti sünnitada, jõuda oleva olemise mõistmiseni on aga ilmselt võimalik üksnes vaikuses, mis samuti kõneleb. Vaikus kõneleb, niivõrd-kuivõrd ta on seotud inimesega ning need kõnelused tulenevad samuti keele loomusest. See on keel, milles peitub vaikusevõimalus (vrd Picard 1948: 32 jj) ehk Jaan Unduski (1994: 68) sõnutsi vakatamisvõimalus. Sõna omandabki tõelise kaalukuse alles talle järgneva vaikuse kaudu, mis on seda sügavam, mida vaikusetundlikum oli sõna. Näiteks Saksa poeet Hugo von Hofmannstahl on püüdnud luua vaikusega ühtesulanud keelt. Ka Eesti luuletaja Betti Alver on öelnud: räägi tasa minuga, siis mu kuulmine on ergem, aga tühja sõnalärmi kuuldeski mu kõrv ei kuule.

Seega: keele kaudu on inimesele antud võimalus väljendada ka midagi väga olulist. Sõna substantsiaalsuse mõõduks võikski pidada tema vaikusesisaldust ning vaikus alles seeläbi oma täitumuse saavutabki, et temast tekib sõna (Picard 1948: 18 jj). Sarnaselt filosoof Picardile väljendab sisuliselt sama mõtet ka Eesti vaikuseheliloojaks kutsutud Arvo Pärt, kes alates 1976. aastast kasutab kompositsioonitehnikana nn tintinnabuli stiili, mida iseloomustab lakoonilisus, n-ö väheste sõnade ehk nootide kasutamine. Pärt, mõtiskledes pausi ja vaikuse üle, on öelnud järgmist:

Enne kui keegi midagi ütleb, peaks ta võib-olla mitte midagit ütlema. Minu muusika on ikka esile kerkinud peale seda, kui olen kaua vaikinud, vaikinud sõna otseses mõttes. Ideaalselt võttes on paus midagi püha. Vaikus tähendab mulle seda "mittemidagit”, millest jumal lõi maailma. Vaikus on 
täiuslikum kui muusika ise, kuna sisaldab kõikvõimalikku. 1976. aastast alates olen pü̈̈dnud vaikust helidesse valada. (Vaitmaa 1988)

Filosoof Wilhelm Weischedel (1963) on artiklis "Vaikimise keel" leidnud, et vaikimise kaudu on võimalik õppida viit kõige olulisemat asja, mida võiks käsitada ka kui vaikimise keele sõnu. Vaikida võib: 1) oma surelikkusest - vaikuses sõlmib inimene sõpruse surmaga; kui osata kuulata, võib lahti saada oma alateadlikust surmahirmust; 2) oma sügavast seotusest kõigi teiste inimestega, kui võtta seljast valjult kõnelemise valeriided; 3) iseendast - hakkame kuulma oma südametunnistuse häält, mis kutsub meid vaikides iseendaks saama; 4) kunstide sõnumist, kuivõrd see on sündinud vaikusest; 5) oleva olemisest tervikuna.

Vaikimist oleva olemisest tervikuna nimetab Weischedel ka sõnaga Stillschweigen, mille A. Liimets on tõlkinud vaikvaikimiseks ehk eriliselt sügavaks vaikimiseks. Kui oleva olemine võib end inimestele väljendada vaikvaikimises, siis järelikult on oleva olemine vaikolemine, täiuslikult täidetud sõnadest tühjenenud olemine. See oleks Jaan Unduski (1994: 95-97) sõnutsi olemine, kus vaikus ja substantsiaalne ainuline Sõna (algupärane Sana) on ühteliibunud, mis tingibki maailma ja inimese taju keelelise häälestatuse. Järelikult võiks oletada, et see, kas meie keelestunud olemises avaldub substantsipüüd või selle kartus, sõltub juba igaühe enda valikust - kas vaikida või lobiseda; kas panna selga valjukõnelise lobisemise valeriided või kogu maailm vaikusega täidetud keeles kodumaastada.

Heidegger (1997) nimetab artiklis "Der Weg zur Sprache" teeks (Weg) keelt kui sellist, samuti inimest kui keelelist olendit/loomust (Sprachwesen). Inimest nimetab Heidegger ka veel lauluks (Gesang) ja luuleks (Dichtung), mida konstitueerib rütm. Rütm loob korduvust, üha uut algust. Tänu rütmilisusele loodub nii inimese kui olemise pidev uuenemine. On ju rütmilisus elu kui sellise põhilisi tunnuseid (vrd Gerhardt 1999). Rütmilisus seostub ka inimese algseimas vormis eneseteadvusega selle ihulis-ruumilisel tasandil (vrd Thibault 2000: 302). Ihulise tunnetuse seostab omakorda kuulmisega Paul Hegarty (2007: 197), kellele sai osutatud ka juba artikli esimeses osas. Tänu rütmilisusele leiab aset sünkronisatsioon inimese ja ta kultuurilise kogemusruumi ning nn antropoloogiliste Teiste vahel. Otseselt rajaneb ihuteadvuste rütmilisele sünkronisatsioonile inimeste näost-näkku kommunikatsioon (Thibault 2000: 302).

Kui lähtuda eeldusest, et inimest kui sellist iseloomustavaks olulisimaks kvaliteediks on eneseteadvus ja minasus (vrd Hamann 1993), siis võiks Heideggeri päristise ise ehk isesuse (Selbstheit) seostada nimelt ihulis-ruumilise tasandi eneseteadvusega, millest saadakse teadlikuks eelkõige kuulmise läbi. See õnnestub, kui inimene on avatud-olekus, milleta Heideggeri järgi pole kuulmine ega vaikimine võimalikud, nagu eespool juba ka viidatud. Kuna päristine 
ise ehk Heideggeri keeli südametunnistus hüüab vaikimise keeles, siis järelikult täiuslikult täidetud, kõikvõimalikku sisaldav ning paljudest sõnadest tühjenenud vaikus kui vaikolemine peitub inimeses (Dasein'is) eneses.

Kui Heidegger nimetab inimest teeks kui selliseks, siis küsime: kust kuhu kulgeb see tee? Kõigest kirjutatust tulenevalt võiks väita, et inimene kui tee püüab luua ligipääsu iseendale ja välismaailmale, jõuda olemistervikusse, kuhu ta endas peituva vaikuse läbi tegelikult ka juba kuulub. Igaühel on see tee aga eripärane. Sünkroniseerumine ja ühendused olemise kui sellisega, maailmaga ning iseendaga on märgistatud igale inimesele omastest tähendustest ja rütmidest. Antud kontekstis mõeldes peame Heideggeri metafoori inimesest kui laulust väga kõnekaks. Samasisulisi mõtteid võib leida isegi eesti rahvaluulest. Väga tuntud on ju järgmised vanasõnad: kuidas lind, nõnda laul; lind laulab nii, nagu nokk on siatud; egal linnul oma laul (Vanasõnaraamat 1984: 553). Mittepäristise ise ehk man selbst'i domineerimise korral inimeses väljendub ta tee aga püüdena vabaneda teda loomupäraselt konstitueerivast individuaalsusest ning oma kokkukuuluvusest olemise kui sellisega. Man selbst ei soovi laulda oma laulu, milleks tal nokk loodud, vaid soovib laule, mis teeks ta sarnaseks kõigi teistega. Siinkohal oleks sobiv meenutada artikli esimesest osast pop- ja tantsumuusika eelistajate konfiguratsiooni, kus lemmikmuusikaks on üleilmselt leviv üheülbaline massikultuur.

Miks kuulata vaikust? Kokkuvõtlikult vastates selleks, et iseneda - saada iseendaks ning vaigistada endas lärmavat man selbst'i. Sealjuures ilmneb iseendaks saamisel paradoksaalsus: s.t vaikus ja suutlikkus vaikida osutuvad nii isenemisprotsessi algus- kui ka sihtpunktiks. Vaikust tuleks kuulata vaikimise õppimiseks ning kokkukuuluvuse ja ühenduste loomiseks maailma ja olemise kui sellisega. Samas suutlikkus olla kuuldel iseenda ning endas peituva vaikuse suhtes on tingimuseks üldse isenemise teele pääsemisel. Seega polekski liialdus lausuda filosoof René Descartes’i parafraseerides: vaikin - järelikult olen.

\section{Kokkuvõtteks}

Käesoleva artikli näol on tegemist interdistsiplinaarse uurimusega, kus on ühendatud kasvatus- ja muusikasotsioloogiline ning filosoofiline vaatenurk muusika kuulamise ja koolinoorte identiteediloome, valjuhäälse lobisemise ja vaikuse/vaikimise temaatikale. Artikli esimene ja teine osa kõnelevad sisuliselt ühest ja samast, kuid erinevas keeles: esimeses osas kõneldakse sotsioloogilistele uurimustele tavapärases keeles, teises osas filosoofilisest vaatenurgast lähtudes. Sotsioloogiline lähenemisviis toob esile empiiriliste andmete statistilise töötluse tulemused ning kirjeldatakse neile tuginedes koolinoorte suhet liiga valju muusika ning erinevate muusikastiilide kuulamisse ning noorte 
vaikusetaluvust kui fenomeni. Teisest osast leiab filosoofilise interpretatsiooni ja seletuse sellele, kuidas ja miks valjuhäälne lobisemine ning vaikimine ja vaikus inimeseks olemises kui sellises omavahel tingimatult seotud on.

Sotsioloogiliselt mõeldes võime öelda, et muusika kuulamine kui tegevus ja sellega seoses tehtavad valikud (s.t kas kuulata eelistatult popmuusikat või klassikalist muusikat vm) leiavad mõtestatuse inimese elustiilitervikust lähtudes. Oluliseks osutub, missugused väärtused kellelegi tähtsad on, missugust tähendust kannavad erinevad tegevused inimese elus. Filosoofilises keeles sama mõtet väljendades võib öelda, et inimese valikud sõltuvad ta ajalisustamisviisidest ehk sellest, kuidas keegi end maailmas olemasolevaks teeb, millelt lähtudes saab oma tähendused ja mõtte.

Inimeseks olemine juurdub keeles ja keele kaudu, mis tingibki maailma ja inimese taju keelelise häälestatuse. Keelelisuse kui fenomeni kaudu on inimeses omavahel seotud valjuhäälne lobisemine, vaikimine, vaikus ja ta isenemine ehk iseendaks saamine. Lobisemine seondub Martin Heideggeri järgi filosoofiliselt mõeldes inimeses ta mittepäristise isega ehk man selbst'iga. Kõneldavas keeles tuleb see ilmsiks läbi kasutatavate nn anonüümsete võõraste sõnade, loosunglike ja stereotüüpsete juttude. Muusikas kui keeles avaldub meie käsituses lobisev kõnelemine üleilmselt leviva meelelahutusliku ja massikultuurilise popmuusika näol. Nagu kinnitasid empiirilised andmed, seostus vaikusekartus samuti pop- ja tantsumuusika kuulamise eelistamisega ning väga valju või valju muusika sagedase kuulamisega. Võib ka öelda, et vaikusekartus väljendab inimese hirmu tal iseenda puudumise ja oma mina illusoorsuse pärast.

Kui küsida, miks üldse kuulata muusikat, siis sotsioloogiliselt mõeldes võib vastata artikli esimese osa pealkirja sõnadega - selleks, et luua oma identiteeti. Ka koolinoored ise väidavad, et nende muusikaeelistused ongi kas täielikult või suuremalt osalt nende 'mina'. Muusika vahendusel identiteedi loomine võib kujuneda aga ka vastuoluliseks protsessiks, mis seondub kuulamise ja kuulmise kui nähtustega. Kuulmine rajaneb aistingulisel tajumisel, haakub inimese ihulisusega - seda kinnitavad nii muusikasotsioloogid kui filosoofid. Meie näeme seoseid kuulmise, vaikimise ning inimese eneseteadvuse algseima, selle ihulis-ruumilisel tasandil avalduva vormi vahel. Samuti leiame, et Heideggeri kõneldud päristine ise inimeses võiks olla paljuski võrreldav nimetatud eneseteadvuse vormiga. Seega filosoofiliselt mõeldes toetab teatud muusika kuulamine inimesel eneseteadvuse kujunemist ning ta iseendaks saamist.

Nagu selgus empiiriliste andmete analüüsist, soodustab vaikimist ning vaikuse suhtes kuuldel olemist klassikaline muusika, samuti jazz- ja pärimusmuusika. Kuna klassikalise muusika eelistamine seostus vaikusearmastuse, väga hästi arenenud refleksiivsusega ja kalduvusega mõtestada oma tegevusi, siis võib järeldada, et klassikalise muusika keel on suure vaikusesisaldusega, 
mis soodustab inimese isenemist. Mitte ilmaasjata ei kasutata ju ka muusikateraapias just klassikalise muusika teoseid.

Valjuhäälselt kõneldava keelena võib aga muusika inimest temast endast kaugemale viia, juhtida ta näivate ja sisust tühjenenud tähenduste võrgustikku, kust väljapääsu leida on vägagi raske. Nõnda pop- ja tantsumuusika kuulamine ei seostugi oma 'mina' loomisega ja selle suhtes kuuldel olemisega, vaid need võimaldavad nii iseenda kui maailmaga üksnes illusoorset kokkukuuluvust. Antud illusoorsus on filosoofiliselt seletatav inimese ja ta maailmasolemise kui sellise paradoksaalsusega. Martin Heideggerist lähtudes peituvad ühes inimeses üheaegselt võimalus olla päristiselt ning luua oma iseolemist, ning olla mittepäristiselt ja toita oma mittetegelikku olemist ehk endas peituvat man selbst'i. See, kumb neist kellegi puhul domineerivamaks kujuneb, sõltub inimese valikutest - kas olla olemas pigem ühel või teisel viisil.

Miks kuulata vaikust? Nagu selgus nii sotsioloogilisest kui filosoofilisest käsitlusest, on vaikusetaluvus ja -armastus seletatavad inimese iseendaks saamise teekonnaga: teatud väärtuste ning enda ajalisustamisviiside eripäraga, inimese suhtega keelde kui sellisesse (s.h muusikasse kui keelde) ning suutlikkusega olla maailmale avatud ning kuuldel vaikuse kõnelusteks. Vaikus inimeses tagab talle kokkukuuluvuse ja ühendused maailma ja olemise kui sellisega, ning aitab hoiduda võõrandumast nii iseendast kui oma elumaailmast.

\section{Kirjandus}

Arifuku, Kogaku 1991. Heidegger und Kant: Uneigentlichkeit und Eigentlichkeit des menschlichen Selbst. Papenfuss, Dietrich \& Pöggeler, Otto (toim). Zur philosophischen Aktualität Heideggers: Symposium der Alexander-von-Humboldt-Stiftung vom 24.28. April 1989 in Bonn-Bad Godesberg. Band 1: Philosophie und Politik. Frankfurt am Main: Vittorio Klostermann, lk 151-166.

Behne, Klaus-Ernst 1997. The development of "Musikerleben" in adolescence: How and why young people listen to music. Deliège, Irene \& Sloboda, John A. (toim). Perception and cognition of music. Hove: Psychology Press, lk 143-159.

Bermúdez, Jose Luis 1998. The Paradox of Self-Consciousness. Cambridge: A Bradfood Book.

Binas, Susanne 2000. Youth Subcultures are Dead!?: On the Cultural Logic of "Generation Z" and the Consequences for Music Educational Concepts. The World of Music 42 (1), lk 125-136 (doi: 10.2307/41699318).

Clayton, H. Mark 2009. The social and personal functions of music in cross-cultural perspective. Hallam, Susan \& Cross, Ian \& Thaut, Michael (toim). The Oxford Handbook of Music Psychology. Oxford \& New York: Oxford University Press, lk 35-43. 
DeNora, Tia 2000. Music in Everyday Life. Cambridge University Press.

DeNora, Tia 2006. Music and Self-Identity. Bennett, Andy \& Shank, Barry \& Toynbee, Jason (toim). The Popular Music Studies Reader. London \& New York: Routledge Taylor \& Francis Group, lk 41-147.

Frith, Simon 1987. Towards an aesthetic of popular music. Leppert, Richard \& McClary, Susan (toim). Music and society: The politics of composition, performance and reception. Cambridge \& London \& New York \& Sydney [etc.]: Cambridge University Press, lk 133149.

Frith, Simon 1996. Performing Rites. On the Value of Popular Music. Cambridge \& Massachusetts: Harvard University Press.

Frith, Simon 2003. Music and Everyday Life. Clayton, Martin \& Herbert, Trevor \& Middleton, Richard (toim). The Cultural Study of Music: a critical introduction. New York \& London: Routledge, lk 92-101 (http://www.posgrado.unam.mx/musica/ lecturas/musicologia/complementarias/nuevaMusicologia/Clayton\%20et\%20al_The\%20 Cultural\%20Study\%20of\%20Music\%202003.pdf - 13. november 2018).

Foucault, Michel 1995. Diskursuse kord: Collège de France’i inauguratsiooniloeng 2. detsembril 1970. Tallinn: Varrak.

Gerhardt, Volker 1999. Selbstbestimmung: das Prinzip der Individualität. Stuttgart: Reclam.

Hamann, Bruno 1993. Pädagogische Anthropologie: Theorien - Modelle - Strukturen Eine Einführung. 2. Auflage. Bad Heilbrunn/Obb.: Klinkhardt.

Hargreaves, David \& Miell, Dorothy \& MacDonald, Raymond 2002. What are Musical Identities, and why are they Important? MacDonald, Raymond \& Hargreaves, David \& Miell, Dorothy (toim). Musical Identities. Oxford: Oxford University Press, lk 1-20.

Hegarty, Paul 2007. Noise/Music: A History. New York \& London: Continuum International Publishing Group.

Heidegger, Martin 1993. Sein und Zeit. 17. Aufl. Tübingen: Max Niemeyer Verlag.

Heidegger, Martin 1996. Identität und Differenz. 10. Aufl. Stuttgart: Neske.

Heidegger, Martin 1997. Der Weg zur Sprache. Unterwegs zur Sprache. 11. Aufl. Stuttgart: Neske, lk 239-267.

Jourdain, Robert 2002. Music, The Brain, and Ecstasy. How Music Captures Our Imagination. New York: Quill.

Laiho, Suvi 2004. The Psychological Functions of Music in Adolescence. Nordic Journal of Music Therapy 13 (1), lk 49-65 (doi: 10.1080/08098130409478097).

Liimets, Airi \& Kruusvall, Jüri \& Mäesalu, Marit 2009. Küsimustik "Pingist pinki" koolinoorte elustiili uurimiseks: 7. täiendatud variant. Tallinn: Eesti Muusika- ja Teatriakadeemia, filosoofilise ja pedagoogilise antropoloogia keskus.

North, Adrian C. \& Hargreaves, David J. \& Hargreaves, Jon J. 2004. Uses of Music in Everyday Life. Music Perception. An Interdisciplinary Journal 22 (1), lk 41-77 (doi: 10.1525/mp.2004.22.1.41). 
Pedusaar, Heino \& Müürsepp, Jaak \& Vabamäe, Inna 2001. Kuulmishoid. Tallinn: Eesti Vaegkuuljate Ühing.

Pehk, Alice 2010. Muusikateraapia. Muusikateraapia Keskus (kodulehekülg http://www. muusikateraapiakeskus.ee/eraisikule/ - 5. november 2018).

Picard, Max 1948. Die Welt des Schweigens. Erlenbach-Zürich: Im Eugen Rentsch Verlag.

Radocy, E. Rudolf \& Boyle, David 2003. Psychological Foundations of Musical Behavior. Illinois: Charles C Thomas Publisher Ltd.

Sarv, Vaike 2002. Helimaastiku mõistest. Muusika 9, lk 30-33.

Schramm, Holger \& Vorderer, Peter 2002. Musikpräferenzen im Alltag: Ein Vergleich zwischen Jugendlichen und Erwachsenen. Müller, Renate \& Glogner, Patrick \& Rhein, Stefanie \& Heim, Jens (toim). Wozu Jugendliche Musik und Medien gebrauchen: Jugendliche Identität und musikalische und mediale Geschmacksbildung. Weinheim \& München: Juventa, lk 112-125.

Selfhout, Martin \& Delsing, Mark \& Bogt, Tom \& Meeus, Wim 2008. Heavy Metal and Hip-Hop Style Preferences and Externalizing Problem Behavior: A Two-Wave Longitudinal Study. Youth \& Society 39 (4), lk 435-452 (doi: 10.1177/0044118X07308069).

Simonett, Helena 2006. Technobanda and The Politics of Identity. Bennett, Andy \& Shank, Barry \& Toynbee, Jason (toim). The Popular Music Studies Reader. London \& New York: Routledge Taylor \& Francis Group, lk 208-215.

Sloboda, John \& O’ Neill, Susan 2001. Emotions in Everyday Listening to Music. Juslin, Patrik \& Sloboda, John (toim). Music and Emotion: Theory and Research. Oxford \& New York: Oxford University Press, lk 415-429.

Sloboda, John \& Lamont, A. \& Greasley, A. 2009. Choosing to hear music: Motivation, process, and effect. Hallam, Susan \& Cross, Ian \& Thaut, Michael (toim). The Oxford Handbook of Music Psychology. Oxford \& New York: Oxford University Press, lk 431-440.

Stahlhut, Christian 1986. Sprache und Ethos: Heideggers Wege zu einer wahrhaften Sprache. Münster: Universität Münster.

Starr, Larry \& Waterman, Christopher 2006. American Popular Music: The Rock Years. New York: Oxford University Press.

Stassen, Manfred 1973. Heideggers Philosophie der Sprache in "Sein und Zeit" und ihre philosophisch-theologischen Wurzeln. Bonn: Bouvier-Verlag.

Sundberg, Johan 1995. Õpetus muusikahelidest. Tallinn: Scripta Musicalia.

Tarrant, Mark \& North, Adrian C. \& Hargreaves, David J. 2002. Youth Identity and Music. MacDonald, Raymond \& Hargreaves, David \& Miell, Dorothy (toim). Musical Identities. Oxford: Oxford University Press, lk 134-150.

Thibault, Paul 2000. The Dialogical Integration of the Brain in School Semiosis: Edelmann and the Case for Downward Causation. Mind, Culture, and Activity 7 (4), lk 291311 (doi: 10.1207/S15327884MCA0704_04).

Under, Marie 1981. Mu süda laulab. Luuletusi kolmeteistkümnest kogust. Tallinn: Eesti Raamat. 
Undusk, Jaan 1998. Maagiline müstiline keel. Tallinn: Virgela.

Vaikuseminutid = Mis on vaikuseminutid ? Vaikuseminutid - tähelepanu ja meelerahu harjutused kõigile (kodulehekülg: www.vaikuseminutid.ee/mis-on-vaikuseminutid/ 8. november 2018).

Vaitmaa, Merike 1988. Tintinnabuli-eluhoiak, stiil ja tehnika. Teater. Muusika. Kino 7, lk 37-47.

Vanasõnaraamat 1984 = Hussar, Anne \& Krikmann, Arvo \& Sarv, Ingrid (koost). Vanasõnaraamat. Tallinn: Eesti Raamat.

Weischedel, Wilhelm 1963. Die Sprache des Schweigens: Zur Dialektik von Wort und Schweigen. Hiltmann, H. \& Vonessen, F. (Hrsg.). Dialektik und Dynamik der Person. Festschrift für Robert Heiss zum 60. Geburtstag. Kiepenheuer \& Witsch.

Xiropaidis, Georgios 1991. Einkehr in die Stille: Bedingungen eines gewandelten Sagens in Heideggers "Der Weg zur Sprache”. Freiburg [Breisgau]: Universität Freiburg.

\title{
Summary
}

\section{Why Listen to Music and Silence?}

\author{
Airi Liimets \\ Professor of Philosophy and Sociology of Education \\ School of Educational Sciences \\ Tallinn University \\ airi_liimets@yahoo.de
}

\section{Marit Koit}

Lecturer on hourly basis

School of Educational Sciences

Tallinn University

marit.koit@gmail.com

Keywords: becoming-one's self, identity, listening to music, loud music, school youth, silence and being silent, speaking loudly

The present article falls into two major parts. The title of the first part, "Listening to music as the creator of youth identity", gives a partial answer to the question "Why listen to music?" One listens in order to create one's identity. The empirical evidence presented in the first part, which explores the preferences of school youth in Estonia in relation to whether they listen to overly loud music and to music of various styles and whether they tolerate silence, refers to different ways of creating one's identity, as well as to the mental health of our society.

It appeared from our empirical research that listening to music features as number one in the lineup of daily activities of the school youth: it is valid both when they assess the time they dedicate to activities and when they are ranking their areas of interest. Many teenagers like to listen to music with volume turned up, and this has medical 
consequences. The physical consequence is that their hearing suffers damage. The mental consequence is that their relationship with one another and with the world suffers damage, which manifests itself in alienation, consumerism, and fusing in entertainment. All this is accompanied by fear of silence, which can be explained as a consequence of temporalizing or creating selfhood not from one's own potentiality (Zeitigung). We can also say that fear of silence expresses the fear of one's own vacuity and illusiveness.

Teenagers claim that their "self" is either totally or partly formed by their musical preferences. As it appeared from the research, classical music encourages being silent and alert to silence and this is also valid for jazz and traditional music. Pop and dance music are not related to creating one's own "self", nor to being alert to it - these music styles allow only illusory feeling of affinity with oneself and with the world. While listening to rock music, one's connectedness to oneself and to the world is ambivalent, comprising some features from both configurations named above.

Talking about people who prefer pop and dance music, we can observe paradoxical connections between the person, the music they listen to, and the world around them. The more they seem to relate to the world by the omnipresence of the music and by listening to it, the less it actually is the case, because pop music that has been alienated from individuality as such is not capable of reaching the body of the one who listens to / hears it. It will not become a constituent of their personal space, even though they are convinced that the respective style of music is their true self. The listener of pop music does listen to it, but obviously does not hear it, because this style of music tends to overpower the type of person who lacks both the perception and the knowledge that they exist in this world. These three significant components in the process of listening to music - the listener, music, and the surrounding environment - are linked by illusory meanings and connections through pop and dance music.

The answer to the question how this paradoxicality can altogether occur is found in the second part of this article and is first and foremost based on Martin Heidegger's lingual-philosophical thinking. The paradoxicality of the development of human identity with music as intermediary is explainable with the paradoxicality of being-in-the-world. A person's being-in-the-world is coincidently being-one's-self (Selbstsein) and being-with (Mitsein). A person's being is taking root and is accomplished within his language and via his language, and this is what elicits the lingual tuning of the world and the perception of the human being. Whether it is the aspiration for substance or the fear for it expressed in our lingual being depends on our own choice - whether we prefer silence or idle talk; whether we wear the fake dress of idle talk or transform the whole world into homeland, using the language filled with silences. Just like any other language, music with its embedded silences can support a person who is alert to silence on their journey into themselves. In case music as language is spoken too loudly, it can divert the person on their journey to themselves and they can get trapped in a network of unreal meanings void of content, which is rather difficult to escape from.

Hence language as such unconditionally links the phenomena of loud talk, listening to overly loud music, being silent, silence, human being, and becoming-one's self or journey towards oneself. The second part of this article reveals the content of the connections between the abovementioned phenomena and scrutinizes in a more detailed way the Dasein-language (die Sprache des Daseins) and Heidegger's language of becoming-one's self (die Sprache des Er-eignisses). Why listen to silence? As it transpired from the 
research, tolerance of silence and love for silence, as well as the urge to listen to overly loud music can be explained with the particularity of the process of a person's becomingone's self or the journey towards oneself, one's relation to language as such and one's capacity to be receptive to the world and alert to the talk of silence. The capacity to listen to silence and understand the talk of silence teaches one to transcend one's boundaries, to be one's self so that one can comprehend being, and to reach the understanding of being as such.

While Heidegger claimed that a human being is a way, we claim that a human being as such is a combination of many intertwined ways which are endlessly gyrating in their togetherness. It apparently depends on several factors of being-in-temporalexistence which of these ways will be dominating at any moment of a person's life. This metaphor is also valid when analysing the school youth's mode of listening to music as a phenomenon. People are not inclined to listen to just one style of music - even during one certain period of life they listen to various styles of music. Which of these styles will be affecting the person most relies apparently on how they position themselves in the wholeness of being as such - the liminal value of which is infinity. Openness and ampleness or narrowness and closeness of a human being's identity also depend on the latter. 